\title{
Current issues of the banking system development of the republic of Uzbekistan
}

\section{Gulbahor BAKOEVA ${ }^{1}$ Shohboz IBODULLAEV ${ }^{2}$}

University of World Economy and Diplomacy

\section{ARTICLE INFO \\ Article history: \\ Received January 2021 \\ 15 January 2021 \\ Available online \\ 7 March 2021

Keywords:
Commercial bank
Central Bank
Asset
Capital
Deposit
Credit
Liquidity
Required reserve
Inflation
Refinancing rate

Received in revised form

Accepted 20 February 2021

\section{ABSTRACT}

The article analyzes the current state of the banking system of the Republic of Uzbekistan and identifies problems associated with its development. In particular, such problems as the presence of the problem of unbalanced liquidity in commercial banks, insufficient resource base of banks, a low level of profitability of assets of commercial banks, and a high level of rates of required reserves of the Central Bank were identified.

Also, the article studies the scientific and theoretical views of economists on the development of the banking system.

In the article, on the basis of the analyzes carried out, scientific proposals have been developed aimed at the development of the banking system of the Republic of Uzbekistan. In particular, the ways of increasing the profitability of commercial banks 'assets were developed, the possibilities of strengthening the resource base and increasing the level of banks' liquidity were substantiated, proposals for improving the policy of required reserves of the Central Bank were substantiated.

2181-1415/C 2021 in Science LLC.

This is an open access article under the Attribution 4.0 International (CC BY 4.0) license (https://creativecommons.org/licenses/by/4.0/deed.ru)

\section{Ўзбекистон \\ Республикаси \\ банк ривожлантиришнинг долзарб масалалари}

тизимини

\author{
Калит суцзлар: \\ Тижорат банки \\ Марказий банк \\ Актив \\ Капитал \\ Депозит
}

\section{АННОТАЦИЯ}

Мақолада Ўзбекистон Республикаси банк тизимининг замонавий холати тахлил қилинган ва уни ривожлантириш билан боғлиқ бўлган муаммолар аниқланган. Жумладан, тижорат банкларида баланслашмаган ликвидлилик муаммосининг мавжудлиги, банкларнинг ресурс базасини

\footnotetext{
${ }^{1}$ Doctor of Philosophy in Economics (PhD)University of World Economy and Diplomacy, Tashkent, Uzbekistan

E-mail: gbakoyeva@uwed.uz

${ }^{2}$ Master student, University of World Economy and Diplomacy, Tashkent, Uzbekistan

E-mail: sh_ibodullayev@mail.ru
} 
Кредит

Ликвидлилик

Мажбурий захира

Инфляция

Қайта молиялаш ставкаси етарли эмаслиги, тижорат банклари активларининг рентабеллик даражасини паст эканлиги, Марказий банкнинг мажбурий захира ставкаларининг юқори эканлиги каби долзарб муаммолар аниқланган.

Шунингдек, мақолада иқтисодчи олимларнинг банк тизимини ривожлантириш хусусидаги илмий-назарий қарашлари ўрганилган.

Мақолада амалга оширилган тахлиллар асосида Ўзбекистон Республикаси банк тизимини ривожлантиришга қаратилган илмий таклифлар ишлаб чиқилган. Жумладан, тижорат банклари активларининг рентабеллик даражасини ошириш йўллари ишлаб чиқилган, банкларнинг ресурс базасини мустахкамлаш ва ликвидлилик даражасини ошириш имкониятлари асослаб берилган, Марказий банкнинг мажбурий захира сиёсатини такомиллаштириш таклифи асослаб берилган.

\section{Актуальные вопросы развития банковской системы Республики Узбекистан}

Ключевые слова:
Коммерческий банк
Центральный банк
Актив
Капитал
Депозит
Кредит
Ликвидность
Обязательный резерв
Инфляция
Ставка рефинансирования

АННОТАЦИЯ

\begin{tabular}{l}
\hline В статье анализировано современное состояние \\
банковской системы Республики Узбекистан и выявлены \\
проблемы, связанных с её развитием. В частности, \\
выявлены такие проблемы, как наличие проблеме \\
несбалансированной ликвидности в коммерческих банках, \\
недостаточность ресурсной базы банков, низкий уровень \\
рентабельности активов коммерческих банков, высокий \\
уровень ставок обязательных резервов Центрального \\
банка. \\
Также, в статье изучены научно-теоретические взгляды \\
ученых-экономистов развитии банковской системы. \\
В статье, на основе проведенных анализов, разработаны \\
научные предложения, направленных на развитие \\
банковской системы Республики Узбекистан. В частности, \\
разработаны пути повышения рентабельности активов \\
коммерческих банков, обоснованы возможности \\
укрепления ресурсной базы и повышения уровня \\
ликвидности банков, обоснована предложения по \\
совершенствованию политике обязательных резервов \\
Центрального банка.
\end{tabular}

\section{INTRODUCTION}

The Action Strategy for five priority areas of development of the Republic of Uzbekistan in 2017-2020 specifically states that deepening reform and ensuring the stability of the banking system, the level of capitalization and the deposit base of banks, strengthening their financial stability and reliability, further expanding lending to promising investment projects, as well as small businesses and private entrepreneurship 
are prerequisites for further strengthening macroeconomic stability and maintaining high rates of economic growth [1].

In addition, the Strategy for reforming the banking system of the Republic of Uzbekistan in 2020-2025 states that improving the quality of the loan portfolio and risk management, improving corporate governance, comprehensive transformation of stateowned banks, the introduction of modern banking standards, information technology and software products are the main areas of reform. national banking system [2].

The solution of the above tasks for the development and reform of the national banking system necessitates a scientific study of the problems associated with the development of the country's banking system.

The development of the banking system has been investigated in the scientific works of foreign economists such as J. Sinki [3], F. Mishkin [4], I. Larionova, O. Lavrushin [5], V. Usoskin [6], E. Zhukov [7 ], E. Zharkovskaya [8], N. Valentseva [9], A. Simanovsky [10], R. Olkhova [11], V. Moskvin, A. Tavasiev [12], S. Calderon, K. Schmidt-Hebbel [13], M. Devereux [14]. 0. Sattarov [15], Sh. Ruzmetov [16].

In these works, theoretical and methodological aspects of the development of the banking system are investigated and the corresponding conclusions are formulated.

\section{THE PURPOSE OF THE STUDY}

The purpose of the study is to identify urgent problems associated with the development of the banking system and the development of scientific proposals aimed at solving these problems.

Large commercial banks and foreign transnational banks - Bank of America (USA), Deutschebank (Germany) were selected as the object of research.

Also, the article examines individual monetary policy instruments of the Central Bank of Uzbekistan. Currently, two instruments of the Central Bank's monetary policy (required reserves policy and refinancing policy) are widely used to influence the liquidity of commercial banks and regulate the money supply in circulation.

\section{MATERIAL AND RESEARCH METHODS}

When writing the article, the official statistical data of the Central Bank of the Republic of Uzbekistan, financial reports of domestic commercial banks (Asakabank, Turonbank) and foreign transnational banks (Bank of America, Deutschebank) were used.

The research used such methods of scientific research as the method of expert assessment, induction and deduction, methods of statistical and financial analysis.

\section{RESULTS AND ITS DISCUSSION}

The banking system of Uzbekistan is two-tier. The Central Bank is at the first level, and commercial banks are at the second level.

As of January 1, 2021, 33 commercial banks function in the banking system of the Republic of Uzbekistan (13 of them are state-owned banks) [17].

The role of the banking system in the development of the national economy is determined by lending to subjects of economic relations, organizing non-cash payments and cash circulation, ensuring the stability of the national currency, ensuring a low and stable level of inflation. In turn, the increasing role of the banking system in the development of the national economy depends on the following factors:

- liquidity and solvency of commercial banks; 
- stability and sufficiency of the banks' resource base;

- the perfection of the monetary policy of the Central Bank.

Table 1

The structure of assets of commercial banks of the Republic of Uzbekistan [18]

(in percent's)

\begin{tabular}{|l|l|l|l|}
\hline Assets & $2018 \mathrm{y}$. & $2019 \mathrm{y}$. & $2020 \mathrm{y}$. \\
\hline Cash at the box office & 2,5 & 2,4 & 3,0 \\
\hline Cash at the Central Bank & 5,3 & 5,4 & 3,8 \\
\hline Funds in other banks & 9,3 & 9,4 & 7,9 \\
\hline Investments in securities & 1,1 & 1,2 & 2,8 \\
\hline Loans & 76,8 & 76,1 & 75,2 \\
\hline Accrued interest on assets & 1,4 & 1,2 & 2,4 \\
\hline Fixed assets & 1,6 & 2,1 & 2,3 \\
\hline Other assets & 3,4 & 4,6 & 2,6 \\
\hline Assets - total & 100,0 & 100,0 & 100,0 \\
\hline
\end{tabular}

As can be seen from the given data in Table 1 , in the structure of assets of commercial banks, the largest share is occupied by loans. This is due to the fact that commercial banks are lending institutions.

The given data show that investments in securities occupy a very low share in the structure of commercial banks' assets. This indicates that the investment operations of banks with securities are underdeveloped. However, in 2018-2020, the share of loans in the structure of assets of commercial banks had a downward trend. This decrease is explained by an increase in the share of investments in securities, accrued interest and fixed assets in the structure of assets over the same period.

As can be seen from the data in Table 1, in 2020 the share of funds in other banks in the structure of assets of commercial banks decreased compared to 2019. This decrease is explained by the increase in the share of accrued interest in the structure of assets for this period.

In the developed countries of the world, investments in securities are an important source of income for commercial banks and a prerequisite for ensuring the liquidity of banks.

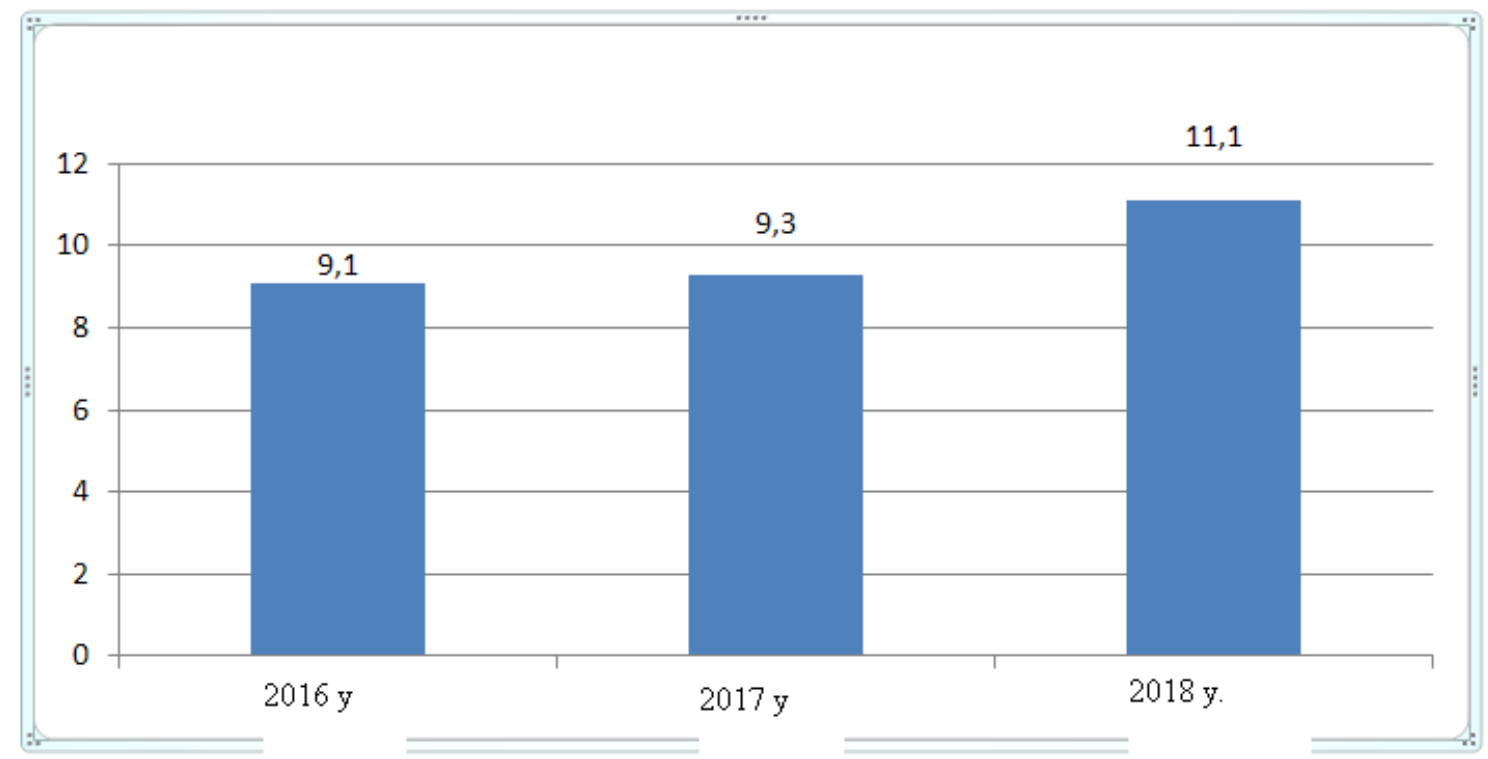

Fig. 1. Share of investments in US government securities in total assets of the Bank of America [19] 
As can be seen from the data in Fig. 1, in the structure of assets of the Bank of America, a relatively large share is occupied by investments in US government securities. These investments ensure the current liquidity of the bank.

One of the main indicators characterizing the quality of the loan portfolio of commercial banks is the level of reserves intended to cover loan losses.

Table 2

The level of provisions intended to cover loan losses in relation to assets commercial banks, percentage [20]

\begin{tabular}{|l|l|l|l|}
\hline & $2016 y$. & $2017 y$. & $2018 \mathrm{y}$. \\
\hline Asaka Bank (Uzbekistan) & 1,4 & 1,8 & 1,7 \\
\hline Deutschebank (Germany) & 0,1 & 0,03 & 0,04 \\
\hline
\end{tabular}

As can be seen from the data in Table 2, in Asakabank, the level of provisions intended to cover loan losses is high. This is assessed as a negative phenomenon in terms of ensuring the quality of the loan portfolio.

The figures show that Deutschebank has very low loan loss provisions.

It should be emphasized that the increase in the volume of active operations of commercial banks directly depends on the sufficiency and stability of their resource base.

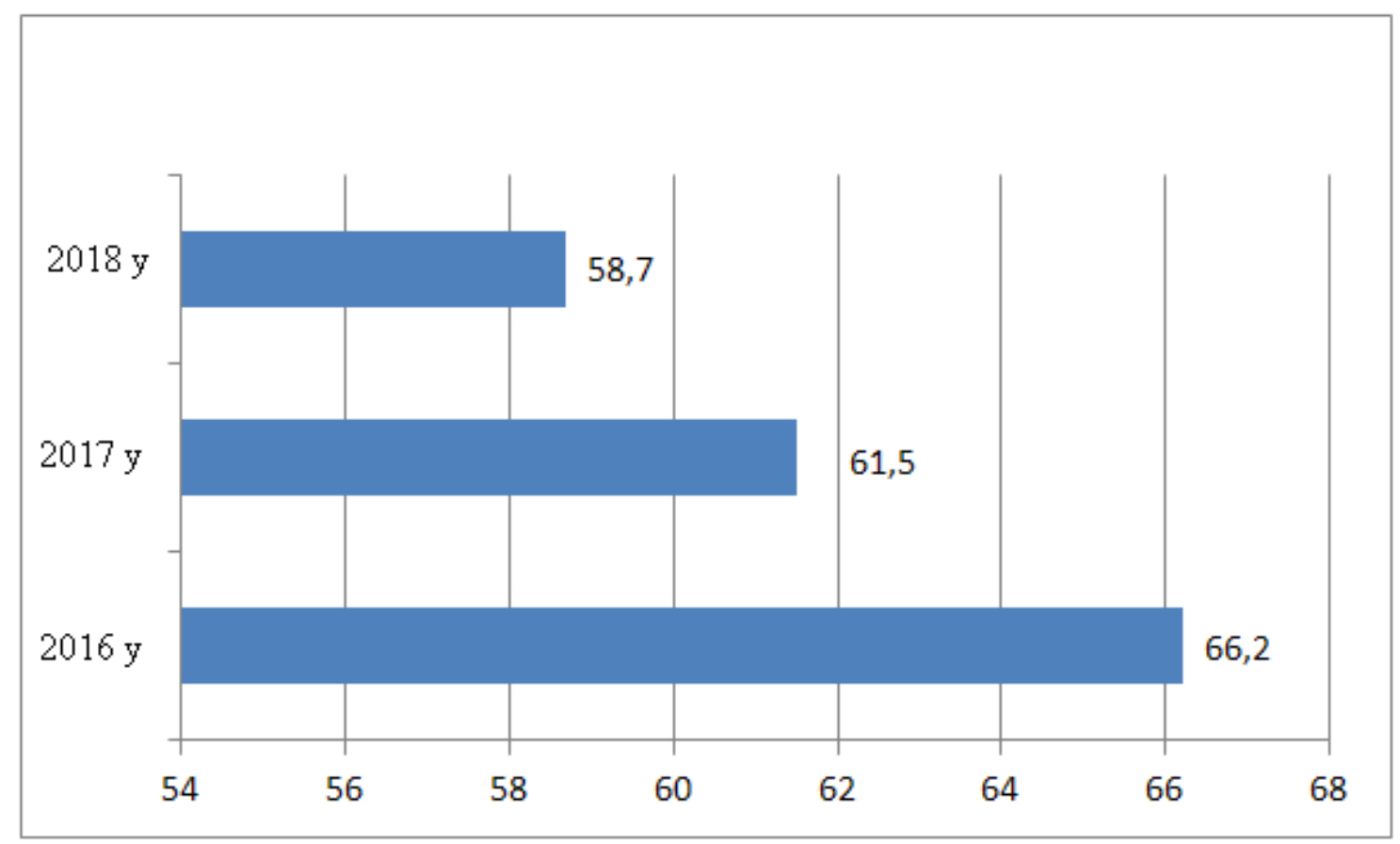

Fig.2. Specific total of transaction deposits in the total volume of deposits of Turonbank [21]

As can be seen from the data presented in Fig. 2, the adequacy of the deposit base is not ensured in Turonbank.

The deposit base of a commercial bank is considered sufficient if the share of transaction deposits in the total volume of deposits does not exceed $30 \%$.

It should be emphasized that at present, the high level of required reserve rates of the Central Bank of Uzbekistan negatively affects the liquidity of commercial banks. 
Since October 1, 2018, the procedure for the formation of required reserves only in the national currency has been introduced, the reserve norms for deposits of legal entities and individuals have been unified and the following rates have been established:

* on deposits in national currency - 4\%;

* on deposits in foreign currency - 14\% [22].

It should be noted that the decrease in the inflation rate enables the Central Bank of Uzbekistan to reduce the refinancing rate.

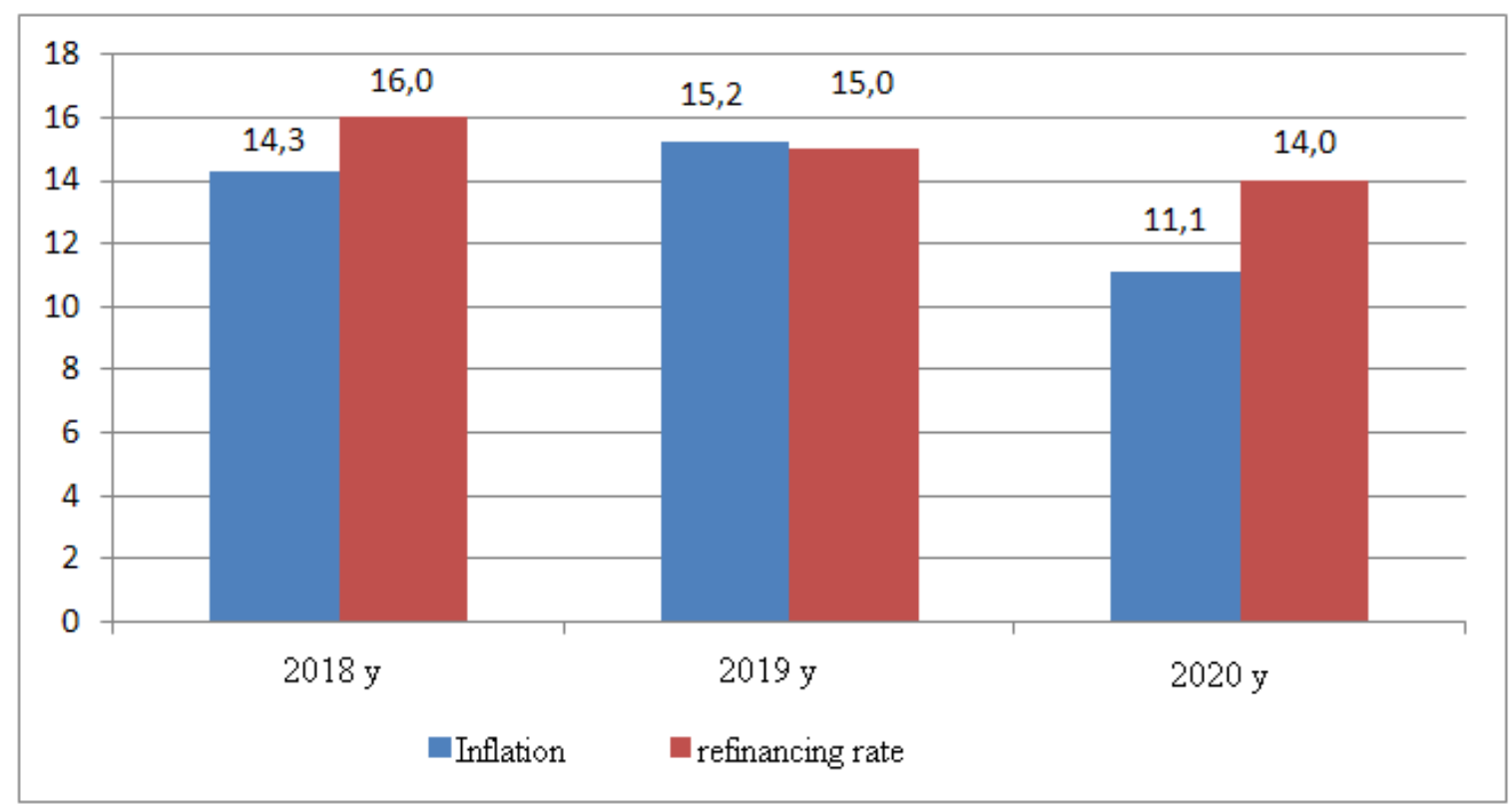

Fig. 3. Annual inflation rate and refinancing rate of the Central Bank in Uzbekistan, \% [23]

As can be seen from Fig. 3, the decrease in the inflation rate in Uzbekistan in 20182020 allowed the Central Bank of Uzbekistan to reduce the refinancing rate.

\section{CONCLUSION.}

As a result of the study, the following conclusions were formulated:

In the structure of commercial banks' assets, the largest share is occupied by loans, but investments in securities take up a very low share. This fact testifies to the indifference of banks' investment operations with securities.

In the structure of assets of the Bank of America, a relatively large share is occupied by investments in US government securities.

In Asakabank, the level of provisions intended to cover loan losses remained at a high level, which is assessed as a negative phenomenon from the point of view of ensuring the quality of the loan portfolio.

At Deutschebank, in 2016-2018, the level of provisions intended to cover losses was very low.

In 2016-2018, the deposit base in Turonbank was insufficient, since the share of transaction deposits in the total volume of deposits exceeds $30 \%$.

The high level of the rates of required reserves of the Central Bank negatively affects the liquidity of commercial banks. 
The decrease in the inflation rate in Uzbekistan in 2018-2020 allowed the Central Bank of Uzbekistan to reduce the refinancing rate.

To solve the problems associated with the development of the banking system of Uzbekistan, it is necessary to take the following measures:

1. To increase the share of investments in securities in the total assets of commercial banks in Uzbekistan, it is necessary: first, to reduce the share of all cash assets in the volume of bank assets by investing them in highly liquid securities; secondly, to buy securities at the expense of a stable balance of transaction deposits in compliance with the principle of diversification of the bank's securities portfolio.

2. It is necessary to ensure the sufficiency of the deposit base of commercial banks by reducing the share of transaction deposits in the total volume of deposits, increasing the share of time deposits by increasing the issue of certificates of deposit, reducing the rate of required reserves of the Central Bank established for foreign currency deposits of commercial banks.

3.In order to eliminate the negative impact of the policy of required reserves of the Central Bank on the liquidity of commercial banks, it is necessary: first, to unify the rates of required reserves on deposits in national currency and foreign currency at the level of $4 \%$ (at the rate of required reserves on deposits in national currency); secondly, it is necessary to eliminate the practice of withdrawing the amount of mandatory reserve deductions from the correspondent account "Nostro" of commercial banks.

\section{References}

1. Decree of the President of the Republic of Uzbekistan No. 4947 dated February 7, 2017 "On the Strategy of Action for the Development of the Republic of Uzbekistan" // Collection of legislative acts of the Republic of Uzbekistan. - Tashkent, 2017. - No. 6 (766). - S. 32.

2. Decree of the President of the Republic of Uzbekistan No. 5992 of May 12, 2020 "On the Strategy for reforming the banking system of the Republic of Uzbekistan in 20202025" // National database of legislative acts: 06/205992/0581. May 13, 2020

3. Sinky J. Financial management in a commercial bank and in the financial services industry. Per. from English - M .: Alpina Publisher, 2017 .-- 1018p.

4. Mishkin F.S. The economic theory of money, banking and financial markets. / Per. from English - M .: LLC "I.D. Williams ", 2013. - S. 880s.

5. Larionova I.V. Commercial bank liquidity. Banking. Ed. O.I. Lavrushin. - M .: KNORUS, 2016. $-800 \mathrm{p}$.

6. Usoskin V.M. Modern commercial bank: management and operations. - M .: LENAND, 2019 .-- 328 p.

7. Zhukov, E.F. Banking. - M .: UNITI, 2011 -- 687s.

8. Zharkovskaya E.P. Financial analysis of the activities of a commercial bank. Textbook. - M .: Omega-L, 2010 -- 325 p.

9. Valentseva N.I., Larionova I.V. Assessment of financial stability and prospects for the activities of credit institutions. - M .: KNORUS, 2018 .- 242 p.

10. Simanovskiy A.Yu. Basel Principles for Effective Banking Supervision and Their Implementation in Russia. // Money and credit. - 2001. - No. 3. -FROM. 19-24.

11. Olkhova, R.G. Banking: Management in a Modern Bank. - M .: KNORUS, 2011 .-298s.

12. Moskvin, V.A., Tavasiev, A.M. Banking. - M .: UNITI, 2007 -- 288 p. 
13. Calderon C., Schmidt-Hebbel K. What Drives Inflation in the World // Central bank of Chile Working Papers, 2008. - No. 491. - P. 1-20.

14. Devereux M.B., Engel C. Monetary Policy in the Open Economy Revisited: Praice Setting and Exchange Rate Flexibility // NBER Working Paper, 2000. - No. 7665. - P. 765783.

15. Sattarov O.B Uzbekistan Respublikasi bank tizimi barqarorligini ta`minlash metodologiyasini takomillashtirish. I.f.d.ilm.dar.ol.uch.diss.avtoreferat-Tashkent,2016- $\mathrm{p}$ $-70$

16.Ruzmetov Sh.B Uzbekistan tijorat banklari deposit bazasini mustahkamlash yullari. I.f.d.ilm.dar.ol.uch.diss.avtoreferat.-Tashkent,2009- p - 18

17. Credit organizations. www.cbu.uz (Central Bank of the Republic of Uzbekistan).

18. Consolidated balance of commercial banks. www.cbu.uz (Central Bank of the Republic of Uzbekistan).

19. Annual Reports. Concolidated Balance Sheet. http://www.bankofamerica.com (Bank of America).

20. Asakabank. Balance sheet. www.asakabank.uz; Annual Reports. Concolidated Balance Sheet. Concolidated Statement of income.www.db.com (Deutschebank).

21. Turonbank. Balance sheet. www.turonbank.uz.

22. Annual report of the Central Bank of Uzbekistan at the end of 2018. www.cbu.uz (Central Bank of the Republic of Uzbekistan).

23. Monetary policy. www.cbu.uz (Central Bank of the Republic of Uzbekistan). 